\title{
Comparative Analysis between Typical and Actual Occupancy Profiles on Energy Consumption and Thermal Comfort Retrofitting Measures: Case Study
}

\author{
Mohamed Amer ${ }^{1}$, Vu Hoang ${ }^{2}$, Christian Frenzel ${ }^{2}$ \\ ${ }^{1}$ Sustainable Building Design Lab, Faculty of Applied Sciences, Université de Liège, Belgium \\ ${ }^{2}$ Transsolar Energietechnik GmbH, Stuttgart, Germany
}

\begin{abstract}
The right determination of occupant's behaviour is essential to eliminate high margins of inaccuracy between simulated and actual building performance. Accordingly, this research aims to present a comparative analysis between the results of retrofitting measures based on typical and actual occupancy profiles in hot climate.

A typical residential apartment in Cairo was selected for monitoring of indoor air temperature and occupancy during a period of one year. The measurements and specifications are used as inputs for calibrating a dynamic simulation model using TRNLizard - an open source TRNSYS simulation tool for Grasshopper and Rhinoceros. A sensitivity analysis has been conducted based on a set of variables on both typical and actual occupancy profiles in order to compare effects of occupancy profile on defining optimization measures for energy retrofitting.
\end{abstract}

\section{Introduction}

In the past 60 years, Cairo has been transformed dramatically by the global dynamics of urbanization that increased the population of the city more than six times (GTZ). Almost half of Egypt's population lives in slum conditions. In greater Cairo, it counts for eight million dwellers living in informal settlements (UNHabitat, 2007). Such numbers indicate the gap between the supply and demand when it comes to housing, allowing more informality to take place. The transformation lead to a dramatic change in housing typologies and on the prevailed used building materials.

Accordingly, there is an obvious increase in the energy consumption in the as shown in Figure 1. That is due to the increase of urbanized areas, loads on an aging infrastructure, not to mention the increasing usage for electrical devices especially Air Conditioners (AC) in parallel to the yearly increasing temperatures especially during summer periods (EEHC, 2013).

Between the years 1996 and 2006, the sale of ACs units has exceeded 54,000 units, and the demand continued to increase to reach up to 766,000 units per year between 2006 and 2010 (Attia, 2012). Based on the Egyptian Electricity Holding Company's report, residential sector in Egypt consumes up to $42 \%$ of the total energy demand (EEHC, 2013), by which the average consumption of electricity on a monthly basis ranges from $172 \mathrm{kWh}$ for a low income housing unit up to $918 \mathrm{kWh}$ for a high income ones (Afify, 2010).

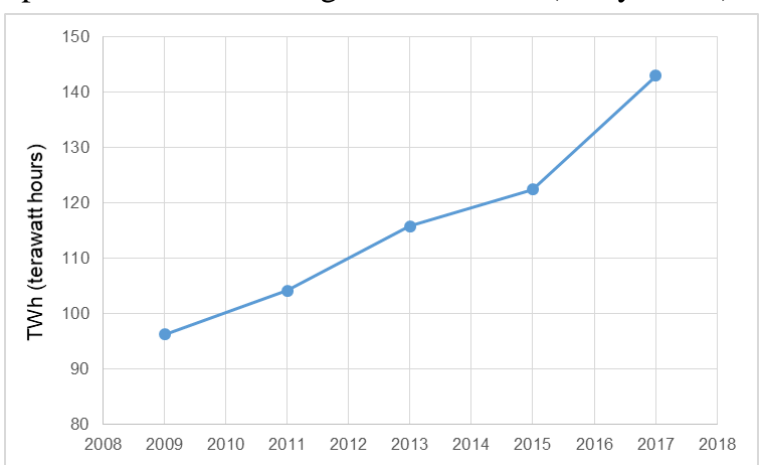

Figure 1: Energy consumption statistics for the residential and industrial sector in Egypt

Despite the high potential that the country has to produce energy from renewable resources such as sun and wind, it heavily relies on hydrocarbon imports, by which it became a net oil importer since 2010. Moreover, energy subsidies count for $20 \%$ to $25 \%$ of government spending, which contributed to rising energy demand and high budget deficit that continues to cut into the country's budget (Plan Bleu, 2007; EIA). Thus, the government planned to reduce the energy subsidies, which was obvious in the latest changes in electricity prices as shown in Table 1 (EEHC; EEUCPRA), by which the increases reached in early 2017 up to $130 \%$ on households.

Table 1: Electricity Prices

\begin{tabular}{|c|c|c|c|c|}
\hline \multirow{2}{*}{ RANGE } & \multicolumn{3}{|c|}{ PRICE IN US Cents } & \multirow{2}{*}{$\begin{array}{c}2015-2017 \\
(\%)\end{array}$} \\
\hline & 2013 & 2015 & 2017 & \\
\hline $1: 200$ & 0.67 & 0.89 & 1.51 & $69 \%$ \\
\hline 201: 350 & 1.06 & 1.34 & 3.07 & $129 \%$ \\
\hline $351: 650$ & 1.62 & 1.90 & 4.19 & $121 \%$ \\
\hline 651: 1000 & 2.96 & 3.35 & 6.98 & $108 \%$ \\
\hline $1000<$ & 3.74 & 4.13 & 7.54 & $82 \%$ \\
\hline
\end{tabular}

There were several trials to cover that deficiency. The Energy and Electricity Ministry went through different agreements and tenders to establish up to eight nuclear power plants with a capacity that should range between 900 and $1650 \mathrm{MW}$ to cover the shortage of electricity supply (World Nuclear 
Association). One of the major root causes is related to the building industry in Egypt. Due to the absence of strict building codes to regulate the built environment for the last 60 years, in addition to the poor technological advancement of the construction industry, it leaded to highly deteriorated building quality (AbdelRazek, 1998). Thus, current dwellings are generally considered to be lacking comfort and being less sustainable.

Some initiative researches attempted to investigate passive measurements for residential buildings aiming to enhance indoor comfort or reduce energy consumption. One research examined different roof section designs via computer simulation and their effect on the indoor thermal comfort. An examination for 37 different roof constructions was conducted for a single room in a typical residential apartment. Brick vaulted roof and high albedo surface showed significant improvement (Dabaieh et al.2015). On the same case study apartment, another research extracted retrofitting solutions for the different façade orientations. In that research, retrofitting glazing components of the apartment was recommended to achieve higher efficiency than the opaque ones (Mohamed and Sherif, 2013). An earlier attempt integrated daylighting and energy consumption in a multi-criteria parametric analysis. For a sample room, different window configurations were examined in different urban contexts, where best-performed configurations were selected (Hegazy et al. 2013). Other researchers focused on outdoor illumination and comfort (Amer and Attia, 2014; Wagdy et al. 2015). However, there is still limitation in previous studies, due to the lack of including precise occupancy behaviour and interaction with the building in both seasons, summer and winter.

\section{Occupant behaviour}

The gap between simulation results and real cases is named as the "performance gap" or "rebound effect" (Motuziene and Vilutiene, 2013). In Boston Chapter of IBPSA, the term "The four Uglies" was raised (IBPSA NEWS), which refers to four parameters: weather, occupancy, plug loads and infiltration, which are considered to be the main factors of uncertainty in building simulation causing performance gaps. Occupant behaviour is hard to predict as many unpredicted factors contribute in altering the behaviour, which cannot be fully integrated yet in the simulation input, such as change in behaviour to achieve a certain level of thermal, visual or acoustic comfort. Several researches tackled occupancy topic between assessing the gap of performance and proposing modelling approaches.

One research assessed four different occupancy profiles and their effect on energy performance. The different assessment focused on the influence of the schedules on heating, lighting and ventilation. It was found that age, number and behaviour have significant impact on the energy simulations (Motuziene and
Vilutiene, 2013). Another research proposed an approach for better occupancy modelling based on improvements in the input and output parameters while considering drivers for different behaviours (Fabi et al. 2011). Hong and Lin defined behaviour in three categories; austerity, represents the most aware and energy saving behaviour, standard for a typical behaviour and wasteful, which is considered to represent the worst-case scenario for an occupant. It showed that the different can achieve $50 \%$ less energy consumption for an austerity behaviour and up to $90 \%$ for a wasteful behaviour (Hong and Lin, 2013).

As for residential buildings, occupancy will highly depend on the functional distribution for the zones as well as on some cultural aspects. In Egypt, contemporary dwellings are still dynamic in terms of space usages, depends on where family members can find their comfort, which include privacy as an initial requirement. Thus, this research presents a modelling approach for actual occupant behaviour for a selected case study, where the investigation takes place.

\section{Methodology}

A typical residential apartment located in the area of Heliopolis district in Cairo is selected for the evaluation study. The apartment hosts a single family consists of three persons. A detailed questionnaire is held for the occupants to define precise occupancy schedules. Occupancy profiles were verified based on three monitoring devices installed in three rooms. Accordingly, two types of occupancy profiles were tested; Typical Occupancy Profile (TOP), based on a previous research that defined a benchmark for Egyptian residential apartments, and Actual Occupancy Profile (AOP), based on the onsite taken measurements and questionnaire. Typical schedule represents a uniform standard usage of the different spaces of the apartment, while actual schedule represents an irregular usage in relation with indoor temperatures that alters the usage of indoor spaces during different periods of the day and seasons.

A sensitivity analysis is conducted for 22 building parameters including the base case to examine the effect of different building envelope variables on each of energy consumption, Hot Kelvin hours (HKh) and Cold Kelvin hours (CKh). The analysis is conducted for both, the typical profile and the other for the actual one. A multi-objective optimization is carried out with the optimization goal of reducing energy consumption as well as discomfort kelvin hours. At the end, a clear comparison highlights the most influential parameters of the building.

\section{Apartment Selection}

Based on the scope and objectives of this research, a real case study was selected to assess the actual building configurations and to monitor occupant behaviour. Five criteria are set for the selection phase, which are: 
- The apartment is located in Cairo to represent the prevailing climate conditions for inhabitants living in a city that hosts more than one fourth the populations.

- The number of occupants range between 3 and 5 users to represent the mean number for a family living in Cairo according to the UNICEF report.

- The apartment should be located in an urbanized area, to match the scope of the research of tackling the problem accompanied with higher energy consumptions

- The apartment should be located on most upper floor, to investigate the effect of roof configuration.

- Trusted voluntary household ready follow up with the research process.

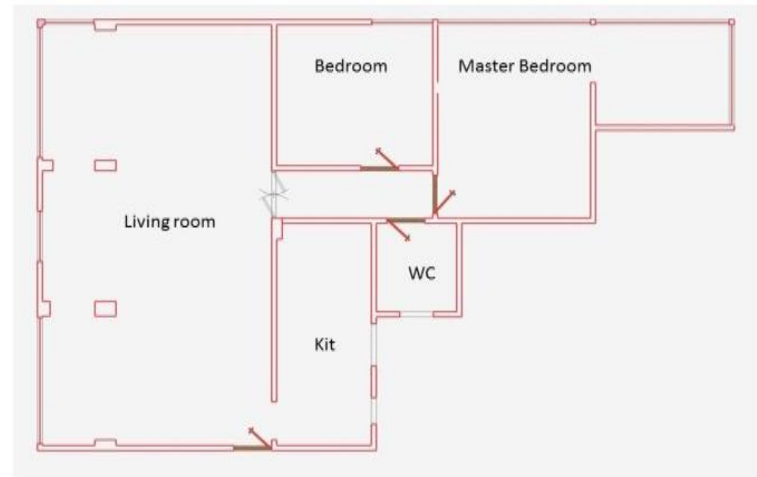

Figure 2: Apartment plan layout

As shown in Figure 2, the apartment consists of a big living room, two bedrooms, kitchen and bathroom. It is important to mention that the initial design of the apartment used to have two balconies; however, to increase the area of the indoor space, the balconies are closed. One air conditioner (AC) is located in each bedroom. Table 2 and Table 3 shows the list of electrical devices used, and building's envelope specifications consequently. The electricity consumed by Air Conditioners highly depends on both occupancy schedules and the indoor temperatures inside the room.

Table 2: Electrical Appliances

\begin{tabular}{|c|c|c|}
\hline Device & Power & Loads \\
\hline TV & $75 \mathrm{~W}$ & \multirow{3}{*}{$0.62 \mathrm{~W} / \mathrm{m} 2 /$ day } \\
\hline Router & $20 \mathrm{~W}$ & \\
\hline Receiver & $20 \mathrm{~W}$ & \\
\hline Fridge & $800 \mathrm{~W}$ & \multirow{3}{*}{$45.78 \mathrm{~W} / \mathrm{m} 2 /$ day } \\
\hline Electric Heater & $1200 \mathrm{~W}$ & \\
\hline Water Cooler & $180 \mathrm{~W}$ & \multirow{2}{*}{$400 \mathrm{~W}$} \\
\hline Dishwasher & $1600 \mathrm{I}$ & \\
\hline Sandwich maker & $750 \mathrm{~W}$ & \\
\hline
\end{tabular}

\begin{tabular}{|c|c|c|}
\hline Washing M & $2100 \mathrm{~W}$ & $7.89 \mathrm{~W} / \mathrm{m} 2 /$ day \\
\hline AC 1 & $3500 \mathrm{~W}$ & \multirow{2}{*}{ Relative } \\
\hline AC 2 & $3500 \mathrm{~W}$ & \\
\hline
\end{tabular}

Table 3: Base Case Building Materials

\begin{tabular}{|l|c|c|}
\hline \multicolumn{1}{|c|}{ TYPE } & DEF & U-VALUE \\
\hline Roof & RC-Sand-Mortar-Flooring & $3.1 \mathrm{~W} / \mathrm{m}^{2} \mathrm{~K}$ \\
\hline Wall & Red Brick wall & $2.47 \mathrm{~W} / \mathrm{m}^{2} \mathrm{~K}$ \\
\hline Glazing & Single tinted Glazing & $5.16 \mathrm{~W} / \mathrm{m}^{2} \mathrm{~K}$ \\
\hline Shading & No Shading & - \\
\hline WWR & $40 \%$ & - \\
\hline Floor & RC-Sand-Mortar-Flooring & $3.1 \mathrm{~W} / \mathrm{m}^{2} \mathrm{~K}$ \\
\hline
\end{tabular}

The weather in Cairo is characterized with high temperature in summer with an average $35^{\circ} \mathrm{C}$, and reaches up to $44^{\circ} \mathrm{C}$ in peak days. While in winter it has an average temperature of $22^{\circ} \mathrm{C}$ and reaches to $9^{\circ} \mathrm{C}$ in peak days. However, there is no heating device installed in the apartment, which is a common practice in Egypt. The average relative humidity is $57.75 \%$, with a maximum average of $68 \%$ in January, and a minimum average of $44 \%$ in May. While the global average daily solar radiation reaches $5.03 \mathrm{kWh} / \mathrm{m}^{2}$ annually.

\section{Occupancy Profiles}

A questionnaire is conducted to the households to define a typical occupancy profile for the simulation process. Actual profile definition has been supported by three monitoring devices in the living room, and the two bedrooms. Monitoring devices measured indoor temperatures and $\mathrm{CO} 2$ levels. Actual $\mathrm{CO} 2$ measurements could identify the time and intensity of occupancy profile, in which has been used to verify the results of the questionnaire. Through out the investigation process, it was found that space usage schedules depend on the indoor temperatures in two ways; firstly, the sitting area is often shifted from the living room to the bedrooms, where they have air conditioners as shown in the comparison between the schedules in Table 4. Secondly, the usage of air conditioner itself was depends on their occupancy time and indoor temperature in the bedrooms.

The operational schedule of the Air Conditioning (AC), which is responsible for cooling loads only, aligns with the occupancy schedules in the summer season only, with a set point operative temperature of $30{ }^{\circ} \mathrm{C}$ (HBRC, 2004). There is no heating system assigined to this model, which is common according to the benchmark of the Egyptian residential apartments (Attia, et al., 2012). 
Table 4: A sample comparison for the living and master bedroom between typical and actual schedules showing the alteration of space usage based on operative temperature

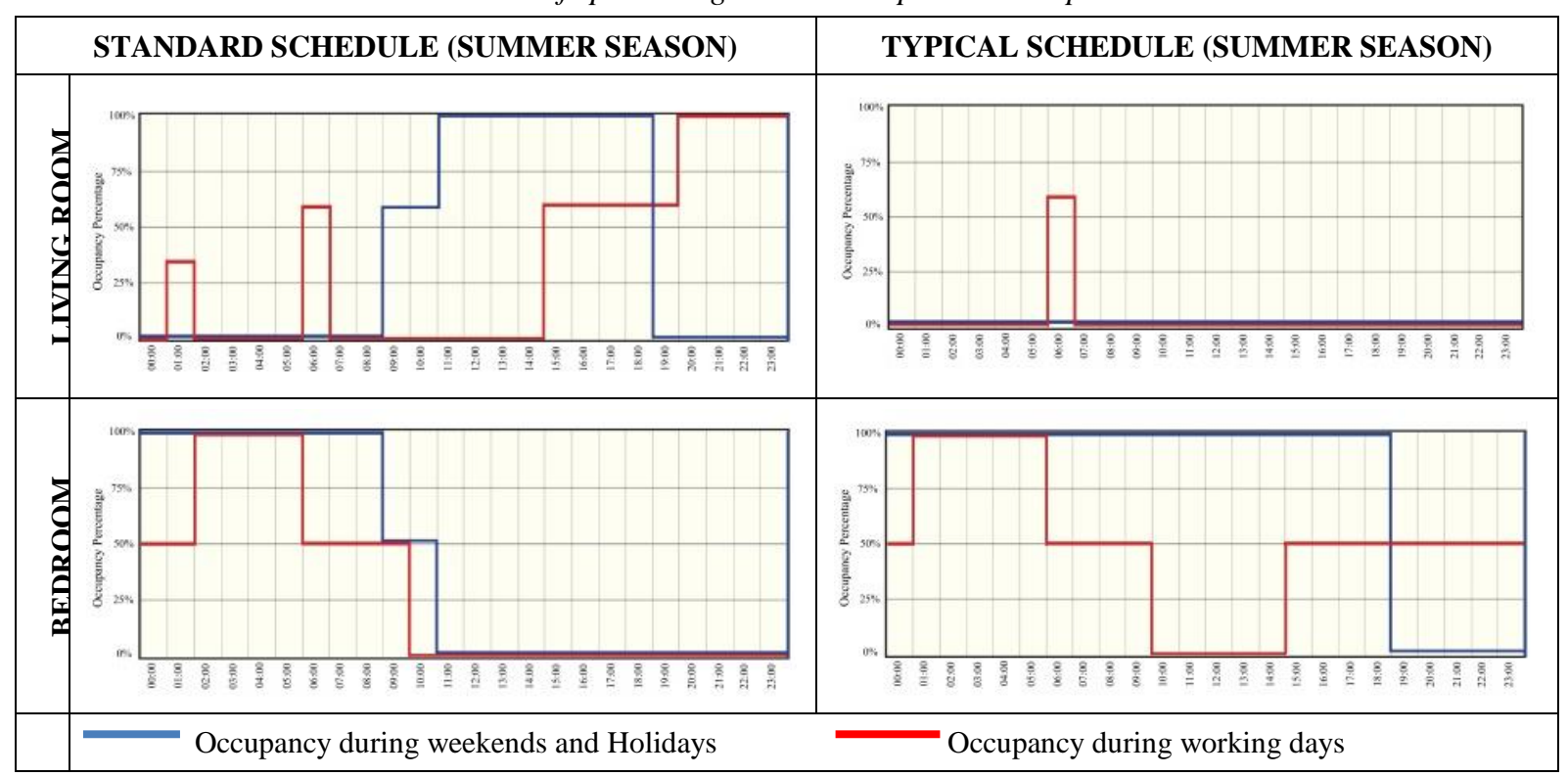

\section{Sensitivity Analysis}

To define the influential building components in the building envelope, a sensitivity analysis has been conducted. The analysis is conducted over five main variables, by which every main variable consists of sub-variable. The main variables are as follows: wall section, roof section, glazing type, window to wall ratio and shading configuration. As shown in Table 5, sub-variables are defined based on the possibilities every variable can have. The total number of variables turned to be 21 .

Table 5: Main and sub-variables specification \& properties designed for sensitivity analysis

\begin{tabular}{|c|c|c|c|}
\hline & SPECIFICAION & PROPERTIES \\
\hline \multirow{7}{*}{$\overline{\bar{\sigma}}$} & 01 & Thick wall & $1.61 \mathrm{~W} / \mathrm{m}^{2} \mathrm{~K}$ \\
\hline & 02 & Light exterior insulation & $0.29 \mathrm{~W} / \mathrm{m}^{2} \mathrm{~K}$ \\
\hline & 03 & Heavy exterior ins. & $0.15 \mathrm{~W} / \mathrm{m}^{2} \mathrm{~K}$ \\
\hline & 04 & Light interior ins. & $0.29 \mathrm{~W} / \mathrm{m}^{2} \mathrm{~K}$ \\
\hline & 05 & Heavy interior ins. & $0.15 \mathrm{~W} / \mathrm{m}^{2} \mathrm{~K}$ \\
\hline & 06 & Light sandwich ins. & $0.27 \mathrm{~W} / \mathrm{m}^{2} \mathrm{~K}$ \\
\hline & 07 & Heavy sandwich ins. & $0.15 \mathrm{~W} / \mathrm{m}^{2} \mathrm{~K}$ \\
\hline \multirow{3}{*}{$\begin{array}{l}\text { ठे } \\
\stackrel{0}{2}\end{array}$} & 08 & Light roof ins. & $0.2 \mathrm{~W} / \mathrm{m}^{2} \mathrm{~K}$ \\
\hline & 09 & Heavy roof ins. & $0.1 \mathrm{~W} / \mathrm{m}^{2} \mathrm{~K}$ \\
\hline & 10 & High albedo & Reflectivity: 0.9 \\
\hline \multirow{4}{*}{$\begin{array}{l}\text {.0 } \\
\text { : } \\
\text { U. }\end{array}$} & 11 & Double glazing (Dbl glz) & $2.83 \mathrm{~W} / \mathrm{m}^{2} \mathrm{~K}$ \\
\hline & 12 & Double glazing + inert & $1.4 \mathrm{~W} / \mathrm{m}^{2} \mathrm{~K}$ \\
\hline & 13 & Dbl glz + inert + eCoat & $1.27 \mathrm{~W} / \mathrm{m}^{2} \mathrm{~K}$ \\
\hline & 14 & Triple glazing + inert & $0.59 \mathrm{~W} / \mathrm{m}^{2} \mathrm{~K}$ \\
\hline
\end{tabular}

\begin{tabular}{|c|c|c|c|}
\hline \multirow{4}{*}{$\sum_{j}^{\alpha}$} & 15 & Single tint glaze & $20 \%$ \\
\hline & 16 & Single tint glaze & $40 \%$ \\
\hline & 17 & Single tint glaze & $60 \%$ \\
\hline & 18 & Single tint glaze & $80 \%$ \\
\hline \multirow{3}{*}{ 胥 } & 19 & Internal shading fraction & $50 \%$ \\
\hline & 20 & External shading fraction & $80 \%$ \\
\hline & 21 & Overhang & Extrusion: $0.6 \mathrm{~m}$ \\
\hline
\end{tabular}

\section{Assessment Criteria}

The standard unit $\mathrm{kWh} / \mathrm{m} 2 / \mathrm{y}$ is used to calculate the energy consumption on the apartment scale, while comfort levels are determined based on the Egyptian code of Energy Efficiency in Residential Buildings. Thermal comfort can be achieved when operative temperature lies between $21.8^{\circ} \mathrm{C}$ and $30{ }^{\circ} \mathrm{C}$, and when humidity levels range between $20 \%$ and $50 \%$ and air velocity is between 0.5 to $1.5 \mathrm{~m} / \mathrm{s}$ (HBRC, 2004). For better assessment criterion, instead of only counting the number of hours that lie outside the comfort threshold levels, the number of hours is multiplied by their intensity measured in Celsius giving the unit of (Kelvin Hours).

\section{Results}

The sensitivity analysis is conducted with the two different occupancy profiles for three different zones; Living room and the two bedrooms. The results are represented in three different charts; Hot Kelvin hours (HKh), Cold Kelvin hours (CKh), and annual energy consumption per meter square $\left(\mathrm{kWh} / \mathrm{m}^{2} . \mathrm{a}\right)$. 


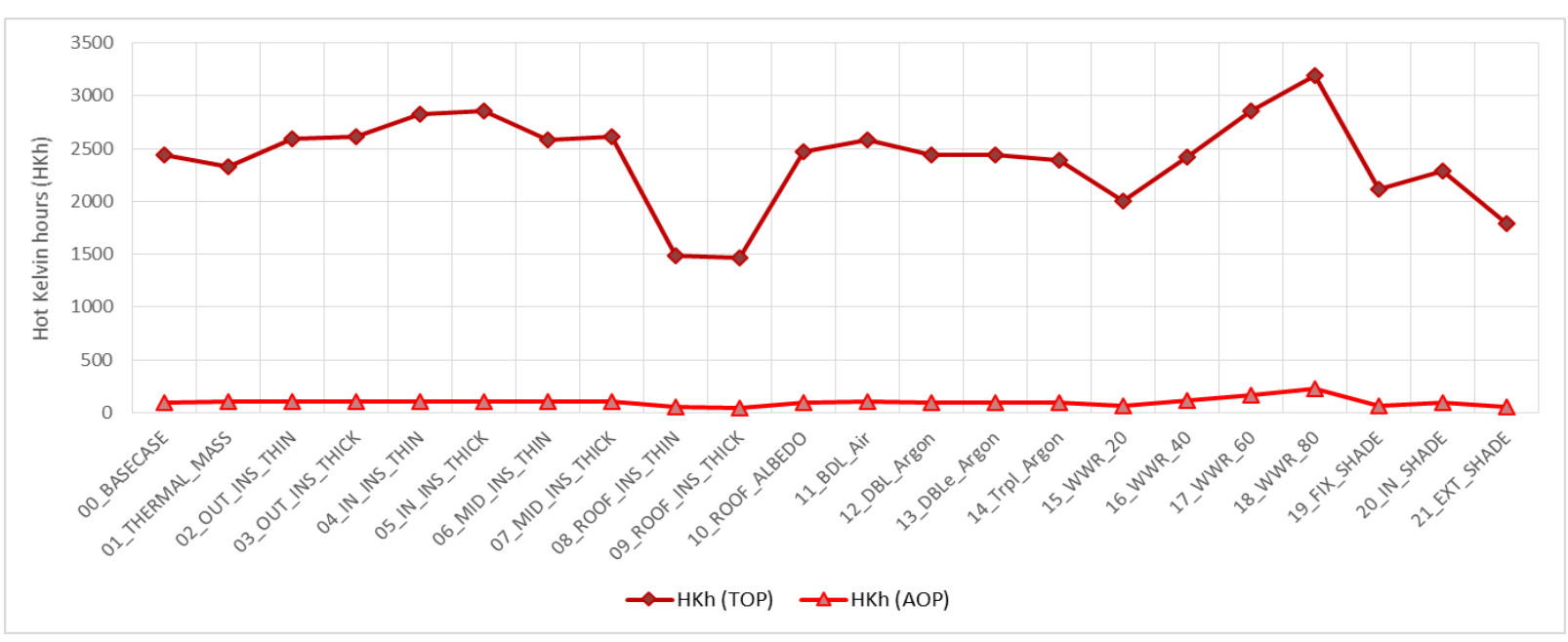

Figure 3: Sensitivity analysis for building envelope's parameters on the Hot Kelvin hour (HKh) using Typical and Actual Occupancy Profiles

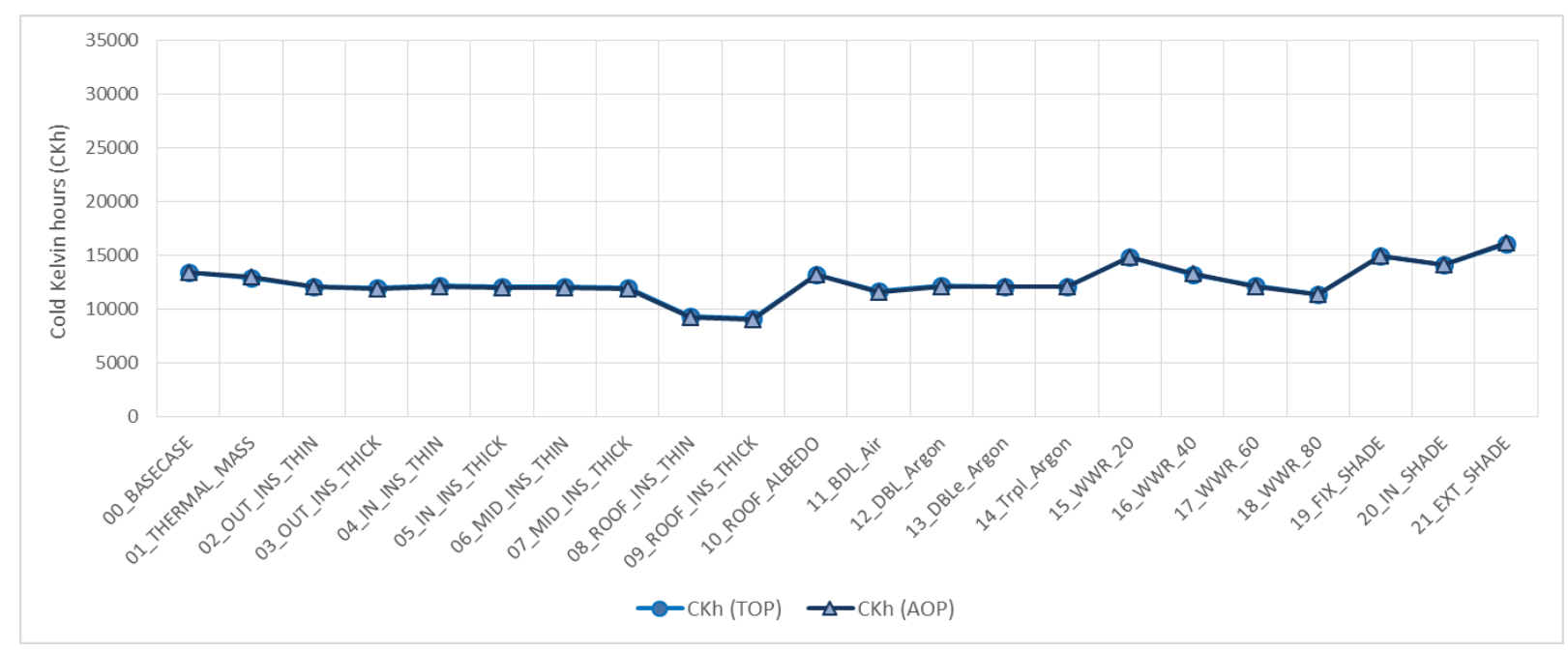

Figure 4: Sensitivity analysis for building envelope's parameters on the Cold Kelvin hours (CKh) using Typical and Actual Occupancy Profiles

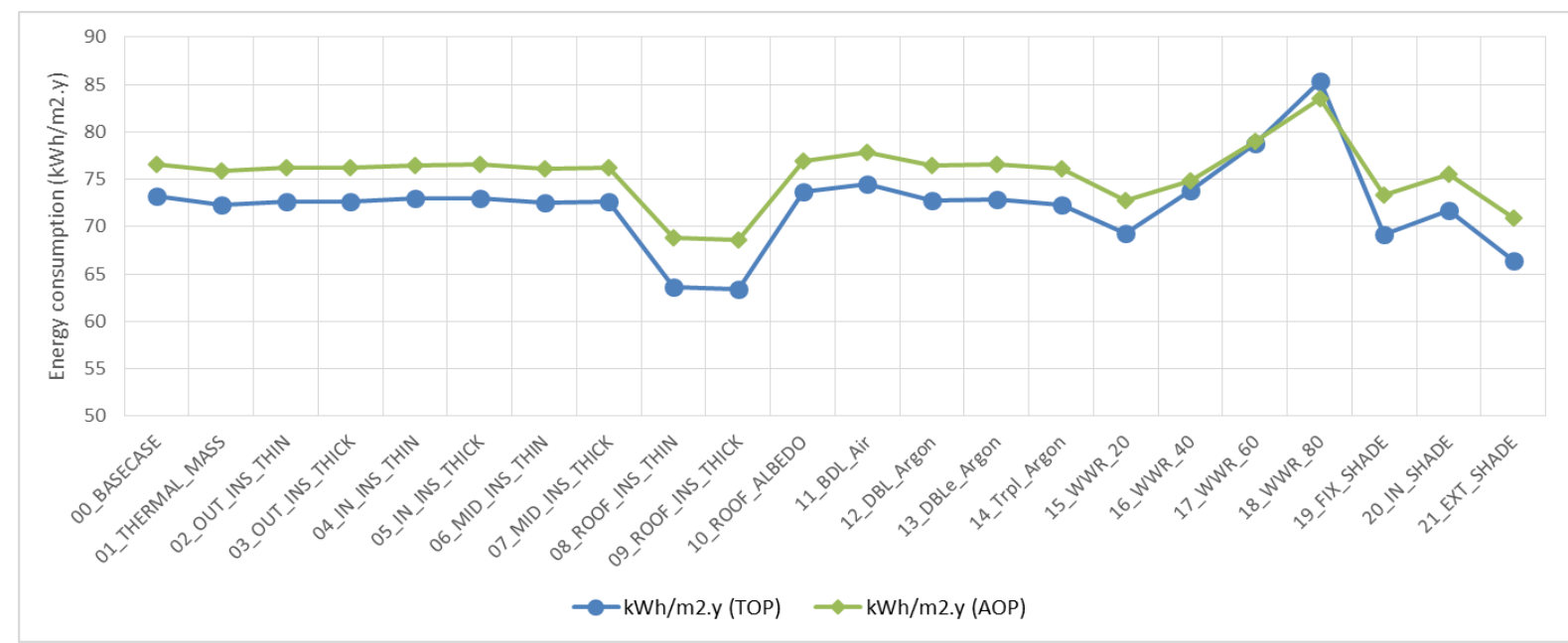

Figure 5: Sensitivity analysis for building envelope's parameters on the energy consumption $\left(\mathrm{kWh} / \mathrm{m}^{2} . \mathrm{y}\right) \mathrm{using}$ Typical and Actual Occupancy Profiles 
According to the simulation on one side, the $\mathrm{CKh}$ values are much higher than $\mathrm{HKh}$ values, which is not hypothetically common for a dwelling in a hot climate region. However, based on the selected evaluated zones, HKh values reflects only the occupancy period in the living room using the typical profile. In the actual profile, $\mathrm{HKh}$ values were barely significant as shown in Figure 3, this reflects the actual behaviour of changing living area to achieve thermal comfort in the air-conditioned rooms. The $\mathrm{CKh}$ values did not change significantly between TOP and AOP as shown in Figure 4. The most significant variable was the roof configuration, by which it achieves a total reduction of $30 \%$ of $\mathrm{HKh}$ for a roof with light insulation and $32 \%$ for a heavy roof insulation. Whereas, Window to Wall Ratio (WWR) of $40 \%$ and more increases the value of $\mathrm{HKh}$, because it increases the amount of radiation from sun and sky during summer which warm up the space. Different insulation thicknesses and positions did not have a great influence on reducing HKh. with an effect that ranges between 9 and $10 \%$ of reductions, which represents the same case with different glazing types. The reason behind that may return to the high infiltration rate of building envelope, which tends to minimize the effect of wall insulation.

In Figure 5, energy consumption for the same variables and on the two occupancy profiles were assessed, which reflects the usage of electric appliances and air conditioning in bedrooms. Due to the shift in occupancy, more energy was consumed during the exceeded period of occupancy in the bedrooms and AC's are on. The base case with the actual profile has a $15 \%$ higher consumption than that with the Typical profile, which highlights the importance of considering better-assessed behaviour profiles during simulation process. Yet, the difference of results between each of the two profiles ranges based on the tested variant starting from $7 \%$ for insulated roof cases up to $21 \%$ for larger window ratios.

The difference in the energy consumption represents the opposite performance of each variable than that for the HKh, which is the amount of hot hours that is translated into energy used for air conditioning. Counting on the actual profiles for better assessment, insulated roof performs even better energy wise, by which a total reduction of $52 \%$ is achieved with light insulation and $53 \%$ for thick insulation. With less window ratio, up to $22 \%$ of reduction is achieved as well as for fixed shading. On one hand, exterior shading has a significant influence, by which $38 \%$ of energy consumption reduction is achieved, however, on the other hand, interior shading achieves only $9 \%$ of reduction. For the other opaque surfaces, different wall insulations achieve by maximum $4 \%$ of reduction, as well as for different glazing types. If we sum up the comfort and energy charts together, it is found that roof insulation has positive influences on both sides, however, window ratio or shading configuration has inversely proportional influence.
Thus, a second iteration of analysis is required for better choice of enhanced combination between different variables.

\section{Optimization}

In this research, the optimization has been carried out using Galapagos, a plugin used in Grasshopper parametric tool, which is based on Genetic Algorithm method of optimization. The aim is to achieve the minimum values for each of energy consumption, Hot and Cold Kelvin hours. The results were later post processed using MATLAB to represent a multiobjective optimization based on Pareto optimality method. Optimization has been carried out for building parameters under each of the TOPs and AOPs as shown in Figures 6 and 7. X-axis represents the sum of Hot and Cold Kelvin hours namely Discomfort Kelvin hours for the three zones (living room, and two bedrooms) for the whole year, while Y-axis represents the energy consumption in $\mathrm{kWh} / \mathrm{m} 2$ annually.

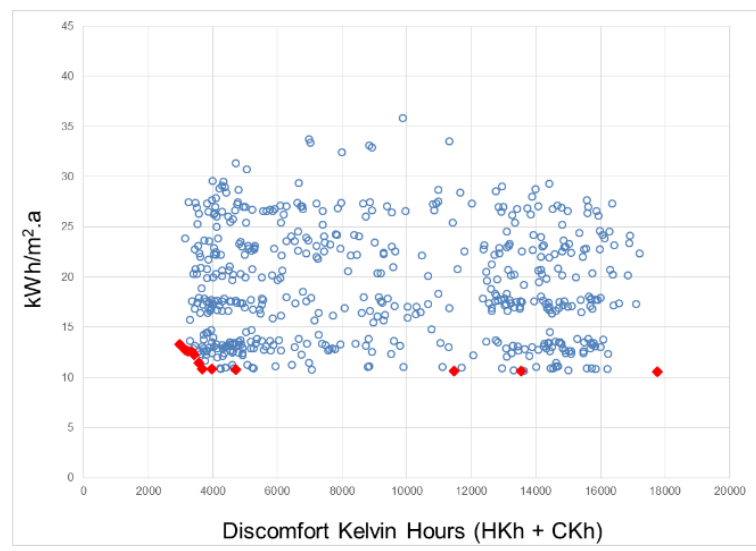

Figure 6: Multi-objective optimization using Typical Occupancy Profile (TOP)

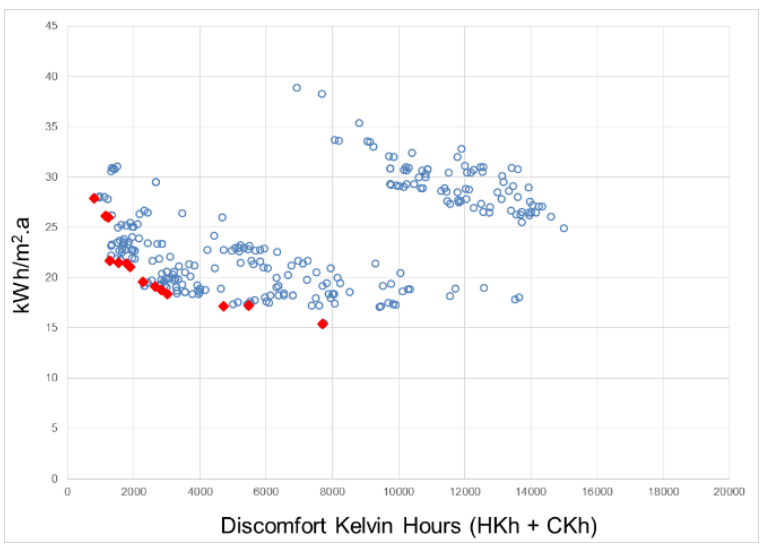

Figure 7: Multi- objective optimization using Actual Occupancy Profile (AOP)

Each attribution of building parameters is represented by one blue cross in the orthogonal graph. In the first optimization process of TOP, 550 iterations where analysed, while the second optimization process of AOP had 250 iterations. The reason behind the difference in the number of iterations of each optimization phase is due to the usage of Genetic Algorithm optimization with a single objective of 
finding the minimum value of both Discomfort hours and Energy consumption. The usage of Genetic Algorithm for optimization has found to show an advantage in narrowing down the number of attributes on which multi-criteria optimization could be carried out. In contrary, exhaustive simulation for a combination of 22 building parameters could reach more than 700 attributions for each simulation occupancy profile. Accordingly, optimum attributes are determined using Pareto Frontier multi-objective optimization method using MATLAB.

Tables 6 and 7 represent the results of Pareto Front from the previous Figures 6 and 7. Out of 550 iterations of TOP, 12 optimum attributes have been defined. Optimum attributes show high diversion of solutions, ranging from using heavy wall insulation to recommendation for high thermal mass, and from using interior shadings to overhangs and no shading at all. Whereas out of 250 iterations using AOP, 14 optimum attributions have been defined. Those attributions have a variation of wall and roof insulation in common, in addition to medium performance glazing resembled in a double glaze with air gap.

Table 6: Optimum attributes using (TOP)

\begin{tabular}{|c|c|c|c|c|}
\hline Wall & Roof & Glaze & WWR & Shade \\
\hline $\begin{array}{c}\text { Thermal } \\
\text { mass }\end{array}$ & $\begin{array}{l}\text { Heavy } \\
\text { ins. }\end{array}$ & Dbl & $20 \%$ & Interior \\
\hline $\begin{array}{c}\text { Thermal } \\
\text { mass }\end{array}$ & $\begin{array}{l}\text { Base } \\
\text { case }\end{array}$ & $\mathrm{Sgl}$ & $20 \%$ & $\begin{array}{l}\text { Over- } \\
\text { Hang }\end{array}$ \\
\hline $\begin{array}{c}\text { Thermal } \\
\text { mass }\end{array}$ & $\begin{array}{l}\text { Base } \\
\text { case }\end{array}$ & Dbl & $20 \%$ & - \\
\hline $\begin{array}{c}\text { Outer } \\
\text { Heavy Ins. }\end{array}$ & $\begin{array}{l}\text { Light } \\
\text { ins. }\end{array}$ & $\begin{array}{c}\text { Dbl + } \\
\text { inert }\end{array}$ & $20 \%$ & - \\
\hline $\begin{array}{c}\text { Outer } \\
\text { Heavy Ins. }\end{array}$ & $\begin{array}{l}\text { Heavy } \\
\text { ins. }\end{array}$ & $\begin{array}{c}\text { Dbl e+ } \\
\text { inert }\end{array}$ & $20 \%$ & - \\
\hline $\begin{array}{c}\text { Outer } \\
\text { Heavy Ins. }\end{array}$ & $\begin{array}{l}\text { Heavy } \\
\text { ins. }\end{array}$ & $\begin{array}{c}\text { Dbl e+ } \\
\text { inert }\end{array}$ & $40 \%$ & - \\
\hline $\begin{array}{c}\text { Inner Heavy } \\
\text { Ins. }\end{array}$ & $\begin{array}{l}\text { Heavy } \\
\text { ins. }\end{array}$ & $\begin{array}{c}\text { Dbl e+ } \\
\text { inert }\end{array}$ & $20 \%$ & - \\
\hline $\begin{array}{c}\text { Outer } \\
\text { Heavy Ins. }\end{array}$ & $\begin{array}{l}\text { Heavy } \\
\text { ins. }\end{array}$ & $\begin{array}{c}\text { Dbl e+ } \\
\text { inert }\end{array}$ & $20 \%$ & $\begin{array}{l}\text { Over- } \\
\text { hang }\end{array}$ \\
\hline $\begin{array}{c}\text { Outer } \\
\text { Light Ins. }\end{array}$ & $\begin{array}{l}\text { Heavy } \\
\text { ins. }\end{array}$ & $\begin{array}{c}\text { Dbl e+ } \\
\text { inert }\end{array}$ & $20 \%$ & $\begin{array}{l}\text { Over- } \\
\text { hang }\end{array}$ \\
\hline $\begin{array}{c}\text { Outer } \\
\text { Heavy Ins. }\end{array}$ & $\begin{array}{l}\text { Light } \\
\text { ins. }\end{array}$ & $\begin{array}{c}\text { Dbl e+ } \\
\text { inert }\end{array}$ & $40 \%$ & - \\
\hline $\begin{array}{c}\text { Thermal } \\
\text { mass }\end{array}$ & $\begin{array}{l}\text { Light } \\
\text { ins. }\end{array}$ & $\begin{array}{c}\text { Dbl + } \\
\text { inert }\end{array}$ & $60 \%$ & - \\
\hline $\begin{array}{c}\text { Outer } \\
\text { Light Ins. }\end{array}$ & $\begin{array}{l}\text { Light } \\
\text { ins. }\end{array}$ & $\begin{array}{c}\text { Dbl + } \\
\text { inert }\end{array}$ & $60 \%$ & - \\
\hline
\end{tabular}

Table 7: Optimum attributes using (AOP)

\begin{tabular}{|c|c|c|c|c|}
\hline Wall & Roof & Glaze & WWR & Shade \\
\hline $\begin{array}{c}\text { Outer } \\
\text { Light Ins. }\end{array}$ & $\begin{array}{c}\text { Heavy } \\
\text { ins. }\end{array}$ & Dbl. & $40 \%$ & $\begin{array}{c}\text { Over- } \\
\text { hang }\end{array}$ \\
\hline $\begin{array}{c}\text { Outer } \\
\text { Light Ins. }\end{array}$ & $\begin{array}{c}\text { Heavy } \\
\text { ins. }\end{array}$ & Dbl. & $20 \%$ & $\begin{array}{c}\text { Over- } \\
\text { hang }\end{array}$ \\
\hline $\begin{array}{c}\text { Middle } \\
\text { Light Ins. }\end{array}$ & $\begin{array}{c}\text { Heavy } \\
\text { ins. }\end{array}$ & Dbl. & $60 \%$ & Interior \\
\hline $\begin{array}{c}\text { Inner Heavy } \\
\text { Ins. }\end{array}$ & $\begin{array}{c}\text { Heavy } \\
\text { ins. }\end{array}$ & Dbl. & $40 \%$ & Interior \\
\hline
\end{tabular}

\begin{tabular}{|c|c|c|c|c|}
\hline $\begin{array}{c}\text { Outer } \\
\text { Heavy Ins. }\end{array}$ & $\begin{array}{c}\text { Heavy } \\
\text { ins. }\end{array}$ & Dbl. & $40 \%$ & - \\
\hline $\begin{array}{c}\text { Outer } \\
\text { Heavy Ins. }\end{array}$ & $\begin{array}{c}\text { Heavy } \\
\text { ins. }\end{array}$ & Dbl. & $60 \%$ & Interior \\
\hline $\begin{array}{c}\text { Outer } \\
\text { Heavy Ins. }\end{array}$ & $\begin{array}{c}\text { Heavy } \\
\text { ins. }\end{array}$ & Dbl. & $60 \%$ & - \\
\hline $\begin{array}{c}\text { Outer } \\
\text { Heavy Ins. }\end{array}$ & $\begin{array}{c}\text { Heavy } \\
\text { ins. }\end{array}$ & Dbl. & $20 \%$ & - \\
\hline $\begin{array}{c}\text { Outer } \\
\text { Heavy Ins. }\end{array}$ & $\begin{array}{c}\text { Heavy } \\
\text { ins. }\end{array}$ & Dbl. & $20 \%$ & $\begin{array}{c}\text { Over- } \\
\text { hang }\end{array}$ \\
\hline $\begin{array}{c}\text { Middle } \\
\text { Light Ins. }\end{array}$ & $\begin{array}{c}\text { Heavy } \\
\text { ins. }\end{array}$ & Dbl. & $40 \%$ & Interior \\
\hline $\begin{array}{c}\text { Outer } \\
\text { Light Ins. }\end{array}$ & $\begin{array}{c}\text { Heavy } \\
\text { ins. }\end{array}$ & Dbl. & $40 \%$ & - \\
\hline $\begin{array}{c}\text { Outer } \\
\text { Heavy Ins. }\end{array}$ & $\begin{array}{c}\text { Heavy } \\
\text { ins. }\end{array}$ & Dbl. & $40 \%$ & External \\
\hline $\begin{array}{c}\text { Inner Heavy } \\
\text { Ins. }\end{array}$ & $\begin{array}{c}\text { Heavy } \\
\text { ins. }\end{array}$ & Dbl. & $20 \%$ & - \\
\hline $\begin{array}{c}\text { Outer } \\
\text { Heavy Ins. }\end{array}$ & $\begin{array}{c}\text { Heavy } \\
\text { ins. }\end{array}$ & Dbl. & $20 \%$ & $\begin{array}{c}\text { Over- } \\
\text { hang }\end{array}$ \\
\hline
\end{tabular}

\section{Discussion and conclusion}

The sequential steps of simulation address the most effective parameters of buildings envelop to achieve indoor thermal comfort and reduce energy consumption. The results from the sensitivity analyses showed that enhancements for opaque surfaces in the building envelope is less effective in terms of energy consumption and comfort, while glazing surface have the priority in consideration. Even though wall insulation does not have a big influence on achieving comfort or reducing energy, it still helps in reducing high infiltration rates, which is considered another important factor that influences the overall energy consumption. Regarding glazing components of the envelope, no shading can be recommended only with a minimum glazing ratio if larger glazing ratio would be applied or the base case, that is more than $20 \%$ in every room, higher shading factor should be considered, whether an overhang, exterior or interior shading. Regarding glazing type, it is always recommended to have at least double-glazing.

A mean difference of $15 \%$ was found between using a Typical and Actual Occupancy Profiles, which highlights the importance of using dynamic occupancy profiles. Primary results of the case study shows that however temperatures in Cairo reach below comfort levels; air conditioners are only used for cooling purposes and never used for heating. Thus, households experience extremely cold days during winter. Given that the general notion on Cairo that it lies in a hot dominated weather, which is true to a certain extend. However, according to the simulation and monitoring results, $\mathrm{CKh}$ have reached up to 14,000 degrees for the base case. In the sensitivity analysis results, $\mathrm{CKh}$ are almost the same during the whole year for two reasons: first, there has not been observed a change in the occupancy pattern during the summer and winter seasons, second, due to the effect of the building's high infiltration values, and the absence of heating system. Therefore, heating systems 
are highly recommended for residential buildings in Cairo.

We found that each of roof insulation and double glazing windows are highly recommended retrofitting parameters to achieve both indoor thermal comfort, during summer and winter seasons, and reduce energy consumption. Both parameters are found to be robustly efficient and feasible no matter what occupancy pattern has been applied in the simulation, given that wall insulation and changing window ratios could require dramatic onsite construction works and the evacuation of occupants. The effect of shading has been found to be efficient during summer season, while in efficient during winter seasons, which is logic. However, and a part of the limitation in this research work, operation schedule of window shadings has not been tested. Thus, we recommend for a future research work that further studies the effect of different operational schedules of windows shading (based on either solar radiation or outdoor temperatures) on the overall thermal and energy performance of the building under such conditions. We also recommend that the further study should include monitored occupancy behaviour towards operating shading devices under different circumstances.

\section{References}

Abdel-Razek R., "Factor affecting construction quality in Egypt: identification and relative importance" Engineering, Construction and Architect Manage 1998;5 (3):220-7

Afify, M. "Rapid Survey of the Key Sectors in Egypt to Facilitate identification of the Potential for CDM project Activities" Interim Report (1), MDG Achievement Fund, 2010

Amer, M., Attia, S. 2014 "Investigation into the Influence of External Walls Reflectivity on the Indoor Daylight Availability in Desert Climates" Conference Proceedings of Building Simulation and Optimization, London, UK.

Attia, S., Evrard, A., Gratia, E. "Development of benchmark models for the Egyptian residential buildings sector" Applied Energy 94 (2012) 270 284

Dabaieh, M., Wanas, O., Hegazy, MA., Johansson, E. 2015. "Reducing Cooling Demands in a Hot Dry Climate: A Simulation Study for non-Insulated Passive Cool Roof Thermal Performance in Residential Buildings" Energy and buildings 89 (2015) 142-152
Egyptian Electric Utility and Consumer Protection Regulatory Agency, Law 1257, 2014

GTZ “Cairo's Informal Areas between urban Challenges and Hidden potential", GTZ 2009

Hegazy, MA., Attia, S., Moro, JL, 2013 "Parametric Analysis for Daylight Autonomy and Energy Consumption for Hot Regions" Proceedings for IBPSA, August, Chambery France

Hong, T., Lin, H. 2013 “Occupant Behaviour: Impact oon Energy Use of Private Offices" berekely National Laboratory

Mediterranean and National Strategies for Sustainable Development, Priority Field of Action 2: Energy and Climate Change, Energy Efficiency and Renewable Energy, Plan Bleu Regional Activity Service, March 2007

Ministry of Housing and Building Research Centre (HBRC), Energy Efficiency Code for Residential Building, Egypt, 2004

Ministry of Electricity and Energy, Egyptian Electricity Holding Company (EEHC), Report 2012/2013

Mohamed, N., Sherif, Y. 2013 "Retrofitting Existing Residential buildings in Egypt" In Proceedings of Sustainable Building Conference, 5-7 Novermber 2013, Cairo, Egypt

Moutziene, V., Vilutiene, T. 2013 "Modelling the Effect of the Domestiv Occupancy Profuiles on Predicted Energy Demand of the Energy Efficient house" 11th International Conference on Modern Building Materilas, Sturcture and Techniques, MBMST 2013

The World Bank. Available from <http://wdi.worldbank.org/table/3.7> [10.5.2015]

The newsletter of the International Building Performance Simulation (IBPSA), Volume 21

UNHABITAT "Chapter 8: The Housing Crisis" Tomorrow's Crises Today: The Humanitarian Impact of Urbanization, OCHA/IRIN \& UNHABITAT, 2007, 74-83

United Nations Development Program. Egypt Human Development Report (EHDR) Report 2005

U.S Energy Information Administration (EIA). Available from< http://www.eia.gov/countries/cab.cfm?fips=EG> [10.5.2015]

Wagdy, A., Ahmed, A., Hegazy, MA. 2015 "Daylighting optimization for informal settlements in Cairo, Egypt" Building Simulation Applications, Bozen, Italy 